\title{
Impacts of Pangasius aquaculture on land use patterns in Mymensingh district of Bangladesh
}

\author{
H. Ali and M. M. Haque \\ Department of Aquaculture, Bangladesh Agricultural University, Mymensingh-2202, Bangladesh \\ Email: ali03ku@yahoo.com
}

\begin{abstract}
Pangasius catfish, Pangasianodoan hypophthalmus farming has been evolved to a shape of commercial enterprise over the last two decades in north-central part of Bangladesh, particularly in Mymensingh area but there is a lack of quantitative and qualitative data on the impacts of it on land use pattern. This study was conducted using multiple methodological tools including participatory rural appraisal (PRA) tools and mainly questionnaire based farm survey to assess the impacts of Pangasius farming on land use from February to September, 2009. The mean farm size (ha), water area (ha) and dyke area (ha) was $1.36 \pm 1.25,1.06 \pm 1.31$ and $0.30 \pm 0.27$, respectively. The Pangasius productivity was significantly and positively correlated with water area and dyke area. Around $10.1 \%$ area of the study area was converted to Pangasius farm which was previously used as rice-field. Farmers expanded their farm area by taking leased lands which contributed to $56.47 \%$ of total farm area and the lease value of Pangasius pond was doubled compared to agriculture land. Around $48 \%$ area of dyke were used to produce agriculture crops and the production was $71.01 \%$ lower but profit margin was $76.58 \%$ higher than normal land. The discharging wastewater of Pangasius pond also increased rice productivity in adjacent agriculture farm by $10 \%$ and additionally reduced fertilizer and irrigation cost by $30 \%$ and $40 \%$, respectively.
\end{abstract}

Keyword: Pangasius aquaculture, impact on land use pattern, Bangladesh

\section{Introduction}

Aquaculture and fisheries together contributes about 5\% of total GDP of the country's economy and 6\% of the total annual export earning. Contribution of aquaculture and fisheries for animal protein accounting for $63 \%$ of the total national intake is still dominating although considerable development was occurred in livestock and poultry sector [Department of Fisheries (DoF), 2009]. Bangladesh's total fish production for the year 2007-2008 was above 2.56 million ton achieving sixth rank among the major aquaculture producing countries in the world (FAO, 2009). Out of total fish production, aquaculture contributes 39\% and remaining $42 \%$ and $19 \%$ was from inland capture fisheries and marine fisheries, respectively [Department of Fisheries (DoF), 2009] indicating aquaculture is the fastest growing food producing sector in Bangladesh.

Regionally, inland aquaculture production is dominated in the north-central region, i.e. the greater Mymensingh district, where Pangasius catfish, Pangasianodoan hypophthalmus farming was started commercially in 1994 by a private fish farm named Al Falah, Mymensingh (Ali, 2009). The estimated total Pangasius production in Bangladesh was about 3, 00,000 tonnes in the year 2008 (Edward and Hossain, 2010 and Munir, 2009). Sarker (2000) reported that amongst exotic fish species, Pangasius is one of the best aquaculture species in Bangladesh due to its ease of culture, high market demand and well suited to the weather condition its propagation and culture. In recent years, Pangasius has become one of the most popular commercial culturable species due to its high yield, higher response to external feeding, and availability of Pangasius seeds to meet up the farmer's demand. Over the last 15 years, Pangasius aquaculture evolved to a shape of commercial enterprise having long backward and forward linkages providing livelihoods for a wide range of stakeholders (Haque, 2009). Almost all of the produces are consumed domestically proving year round supply of animal nutrition to low and medium income people in both rural and urban areas.

Total fish production of the country during the last two decades has increased about three times, from 895,935 tonnes in 1990-1991 to 2563,296 tonnes in 2007-2008 [Department of Fisheries (DoF), 2009]. Such expansion has huge positive impacts as discussed above, however a large concern is that aquaculture has some negative environmental impacts. Expansion of aquaculture requires conversion of land related to crop fields, wetlands, seasonal waterbodies, mangrove forests, and other terrestrial and aquatic ecosystems. Land is the basic natural resource that provides habitat and sustenance for living organisms, as well as being a major focus of economic and livelihood activities (PDOICZMP, 2004). The population is increasing and the land is being converted from productive purposes, such as crop 
cultivation, to other uses such as housing, roads and urban development, and this trend is expected to continue. This is because there is no such a national policy for any systematic land use strategy that was already implemented by other Asian countries (e.g. Vietnam, Indonesia, etc.) consolidating and distributing the land resources to the appropriate users through the control of the government towards sustainable land use (Griffin et al., 2002). Collectively increasing pressure of aquaculture, agriculture and other non-agricultural activities on land use made the scientists and policy makers concerned about sustainability of food production for future generation.

In terms of inland aquaculture, particularly of Pangasius aquaculture in Bangladesh, as there is no any legal aquaculture legislation in place for land use, consequences could be the same as the of shrimp farming in coastal areas (Primavera, 2006). Therefore, the overall environmental impact due to land use for Pangasius farming became an important issue deserves to be addressed thoroughly. Considering the above fact, the present research work was carried out to assess the impacts of Pangasius aquaculture on land use patterns in selected areas in Bangladesh.

\section{Materials and Methods}

This study was conducted in Dhanikhola of Trishal upazila under Mymensingh district (Fig. 1) from February to September, 2009. Ali (2010) reported that Pangasius farming first started by private enterprise in Trishal which was very close of the study village. The authors also reported that the number of Pangasius farms higher in Dhanikhola compared to other areas of Trishal upazila. This village was a typical Pangasius producing area in terms of early development, having large number of farms, higher production level and better access to the markets. There were 135 farms in the study area and out of which, 60 farms were randomly sampled for this study. The information of this study was collected based on questionnaire interview and in addition, key informant interview and focus group discussion. Draft questionnaire were tested with few farmers before preparing final questionnaire. During the testing period, attention was given to include any new information and based on the feedback the final questionnaire was prepared.

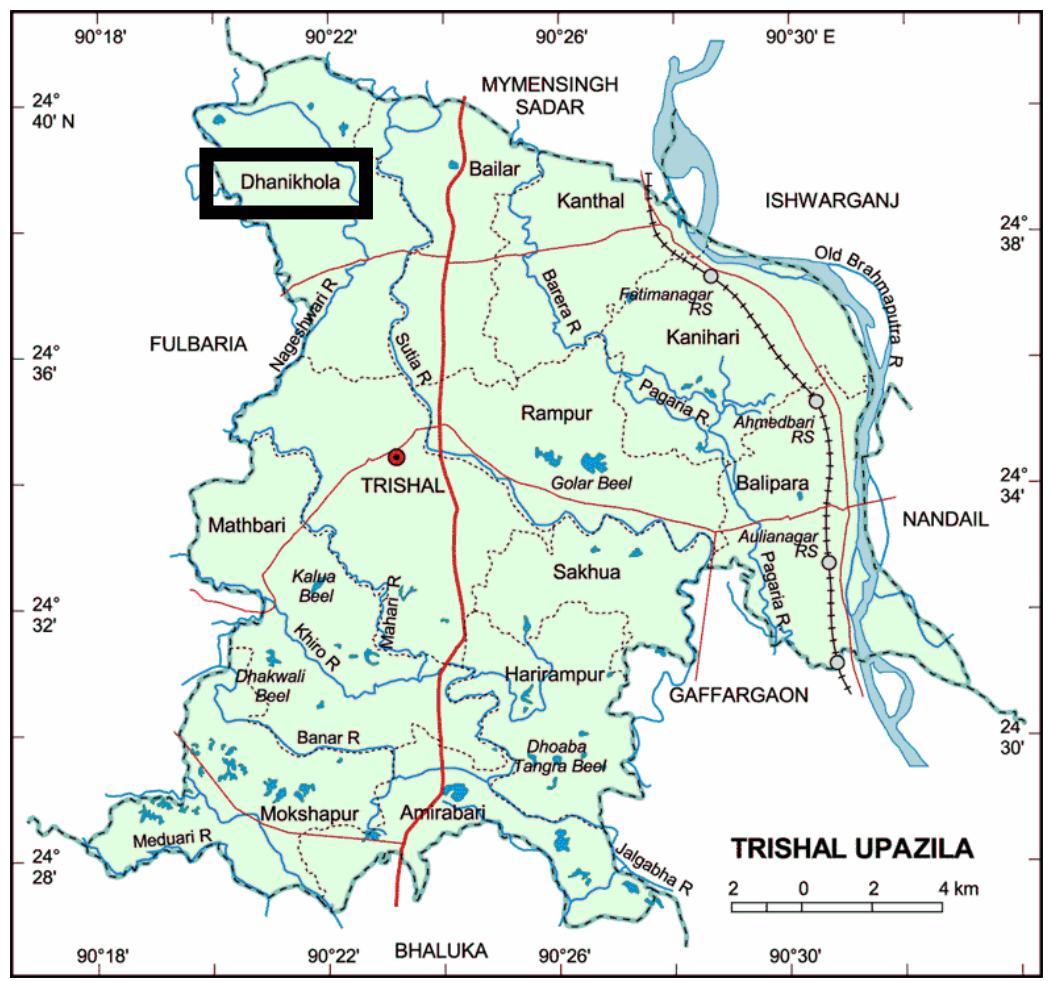

Fig. 1. Map of Trishal upazila showing the study area 
The collected information were entered into the data-base software MS-Excel and analyzed by SPSS (version 11.5). The findings were presented in textual, tabular and graphical forms to explicit impacts of Pangasius aquaculture on land use pattern.

\section{Results and Discussion}

\section{Pangasius farming system}

Farming trends: Total aquaculture production was 1,064,801 tonnes for the year 2008-2009, of which Pangasius production was 59,477 tonnes, accounting for $6.5 \%$ of the country's recorded aquaculture production (DoF, 2010). This data was a substantial increase compared to the year 2007-2008, when the Pangasius accounted for just $3.77 \%$ of reported production. The number of Pangasius farm development over the years shows increasing trend however, it has got a static position during 2007 and 2008 (Fig. 2). In 2009, new farmers have again started farming due to high market price of Pangasius. This figure also suggests that the production of Pangasius aquaculture has significantly increased over the last decade.

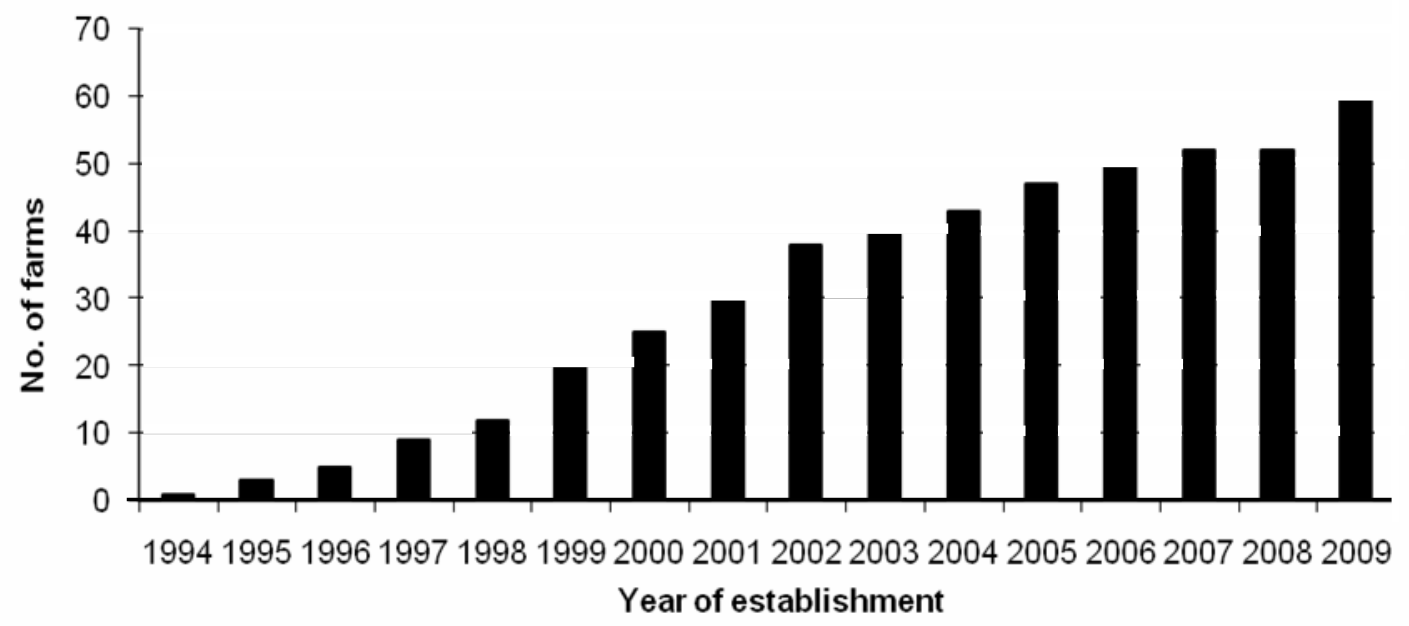

Fig. 2. Cumulative annual growth of Pangasius farms in the study area (source of data: farm survey)

Farm productivity: Most of the farms (66.7\%) in the study area have their own nursery pond and farmer stocked fry in nursery pond before transferring to the grow-out ponds. The remaining farmers (33.3\%) who have no nursery pond purchased fingerling from nursery farmers or traders. Almost all farmers (95\%) purchased carp fingerling from the local fry trader.

The grow-out farming system of Pangasius in Bangladesh is polyculture with carps. The stocking density of Pangasius varied from 1.5 to $9.5 / \mathrm{m}^{2}$ (mean: $4.56 \pm 1.93$ ) depending on fingerling size. The mean stocking density was not significantly different ( $p>0.05$ ) among three study communities. Moreover, farmer also stocked carps fingerling and the stocking density varied from 0.375 to $5 / \mathrm{m}^{2}$ (mean: 1.98 \pm 1.31 ). Ali et al. (2011) reported a similar trend of Pangasius farming in Mymensingh district.

The mean productivity of Pangasius farms was $33.09 \pm 8.65$ tonnes/ha (ranging from 14.82 to 45.43 tonnes/ha) of which Pangasius production varied from 12.84 to 40.56 tonnes /ha (mean: $30.90 \pm 8.54$ ) and carps production $2.20 \pm 1.62$ tonnes/ha (ranging from 0.48 to 5.78 tonnes/ha). No statistically significant difference $(\mathrm{p}>0.05)$ was found among three communities in terms of average production. Ahmed et al. (2010) reported that the Pangasius productivity in Mymensingh district varied from 8.34 to 13.95 tonnes/ha which was significantly lowered compared to the present study. Recently, a study has been conducted by Ali et al. (2011) who reported that the average productivity of Pangasius aquaculture was 40.20 tonnes/ha in Mymensingh district. 
Most of the farmers (60\%) used commercial pelleted feed purchased from local market, $30 \%$ of farmers used farm-made feed and remaining $10 \%$ used both commercial pellet and farm-made feed. Farmer purchased feed ingredients from local market but the quality of the ingredient was not satisfactory. Normally, 6-7 types of ingredients including rice bran or polish, maize meal, wheat flour or wheat bran, dry fish, mustard oil cake, soybean meal, meat and bone meal were used to prepare farm-made feed. In addition, mussels, vitamins, calcium and feed binders were also used.

\section{Impacts on land use pattern}

The present study area covers 2000 ha of which 202.5 ha, that is $10.13 \%$ of total area, was converted from agriculture to Pangasius farm (Source: Trishal Land Office). The sample farmers of the present study used $47.56 \%$ of their land for Pangasius aquaculture and remaining $52.44 \%$ used as rice-field, vegetables etc. (Fig. 3). The results indicated that most of the farmers land is used to generate income by means of Pangasius aquaculture. Similar situation is observed in the coastal area of Bangladesh. More than $80 \%$ of the land in Rampal upazila was under rice cultivation in 1975, whereas in 1999 it decreased to less than $20 \%$. Over that period, most of the rice fields was replaced by rice-shrimp farming as well as only shrimp cultivation indicating sharp decrease of land resources for rice farming (Karim, 2006). Hossain and Lin (2001) also found that most of the suitable areas for mangrove afforestation are currently being used for shrimp and salt production in Bangladesh.

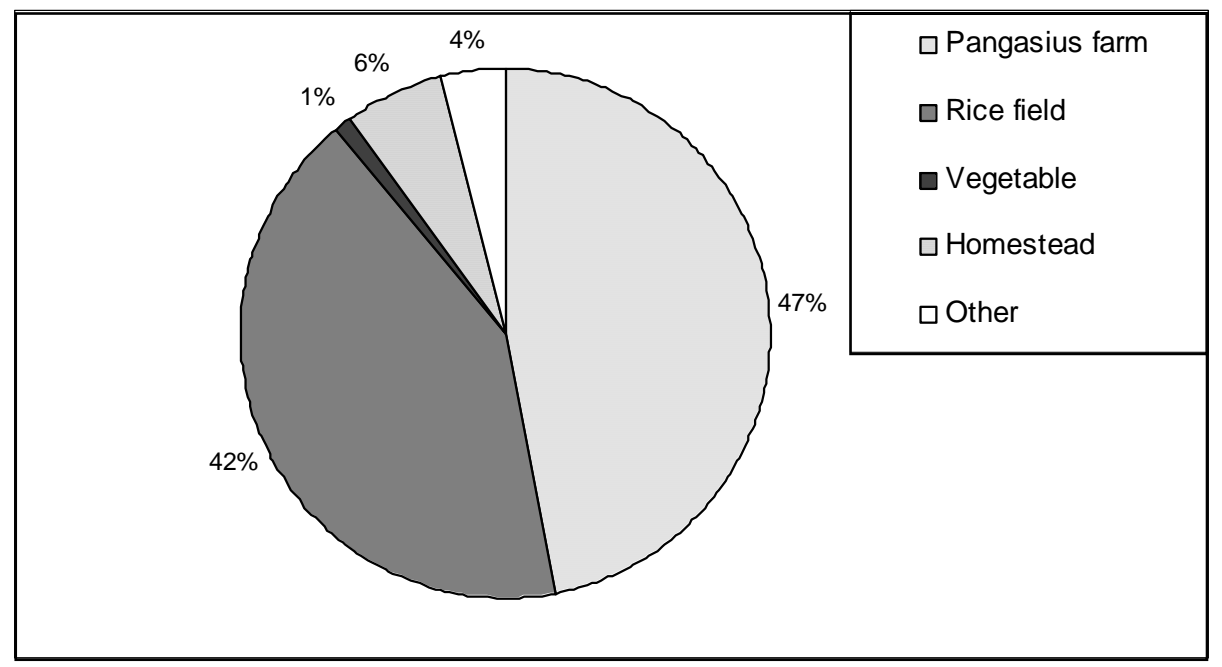

Fig. 3. Land use pattern of Pangasius farmers in the study area (source of data: farm survey)

The introduction of shrimp farming has gradually changed the land-use patterns of the surrounding farms, transforming agriculture and mangrove areas into shrimp-farming areas (Karim, 2006). In the present study, 50\% upland, $45 \%$ low land rice-field and 5\% fellow land were converted to construct Pangasius farms which suggests that upland rice-field was less productive or single crop producing land is mainly used for Pangasius farming. Karim (2006) also reported that about 3.5\% of forest and $2.4 \%$ of pasture land was converted into shrimp ponds. In the present study, the farm size varied from 0.16 to 7.69 ha (mean: 1.36 \pm 1.25 ). Most of the farmer (66.66\%) extended their farm by taking leased lands and it contributed $56.47 \%$ of the total farms. This result implies that Pangasius aquaculture is a profitable business and farmers had tried to extend their farm area which increased the lease value of local agricultural area. The present study revealed that the lease value of Pangasius pond varied from US\$ 705.71 to 1085.71/ha (mean: 935.07 \pm 65.23 ). It was around double compared to agricultural land (571.42 \pm 58.78 ). This trend is significalty higher comapared to shrimp farming in Bagerhat district (Karim, 2006). The average lease value of agriculture land was 314.28 $\pm 17.35 /$ ha before starting Pangasius aquaculture in Bangladesh. As such, it can be concluded that Pangasius aquaculture provided an opportunity for more economic use of land although it is responsible for creating inequity in the society because poorer agricultural farmer were not able to introduce Pangasius farming and ultimately they were not benefited. 
The mean farm sizes (ha), surface/water area (ha) and dyke area (ha) was $1.36 \pm 1.25,1.06 \pm 1.31$ and $0.30 \pm 0.27$, respectively. The water area mainly used as grow-out $(82.45 \%)$ ponds and remaining (17.55\%) used as nursery ponds. Most of the farmers (70\%) used their farm dyke in different extent and remainder (30\%) did not use dyke. The total Pangasius farm production was significantly and positively raised with increasing total surface as well as dyke of area of Pangasius farm (Fig. 4). This again reflects strong message of keeping a large potential area of dyke completely unused that could be used for other agricultural production adopting integrated aquaculture approach (IAA) towards maximizing land productivity and profit margin of farms.

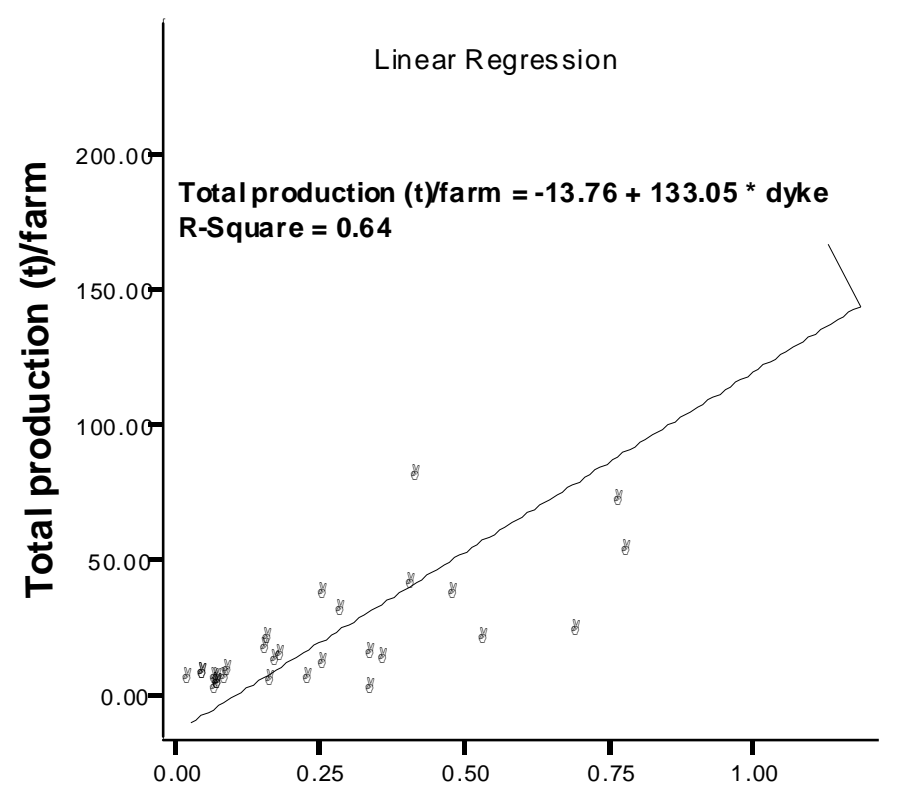

Total dyke area (ha)

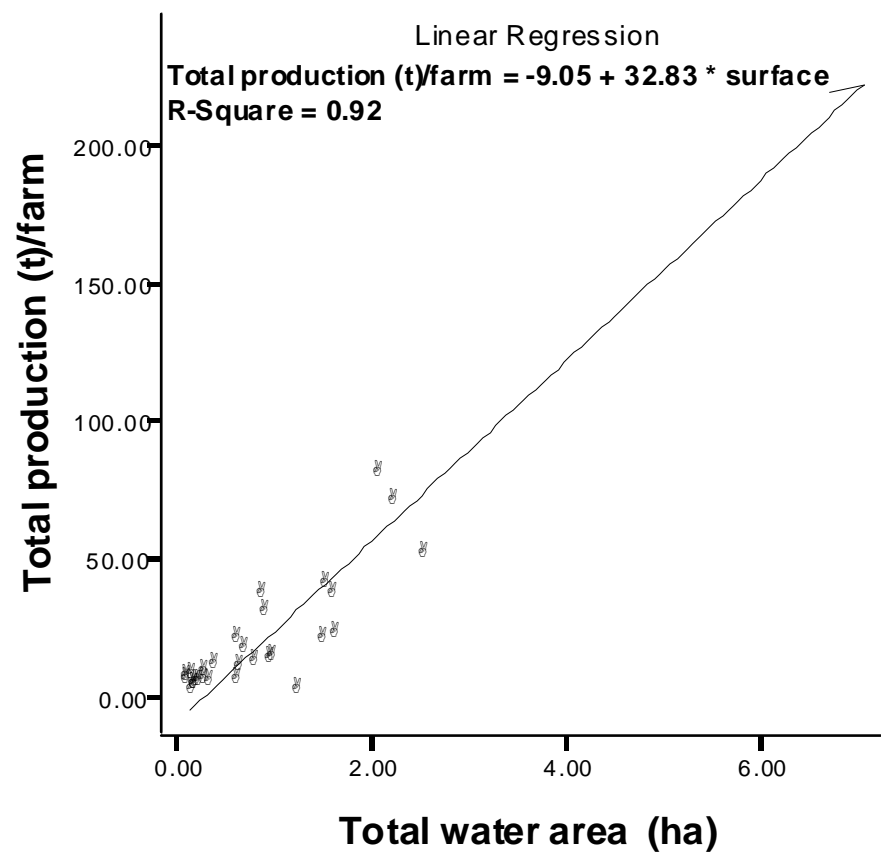

Fig. 4. The relationship between productivity with (a) dyke area and (b) water area (source of data: farm survey) 
The study also revealed that the number of dyke users was high but the amount of land used to produce crops was very low (only 13\%). Out of $13 \%$ of dyke, $48 \%$ of area was used for producing vegetables and remaining area for other purposes (Fig. 5). The vegetable production cost per unit area for dyke cropping was $70.01 \%$ lowered compared to other agricultural farm however, profit margin was $76.58 \%$ higher. The result indicated that major proportion of the dyke was empty although there was a potential scope for producing other crops on the dyke area. In Bangladesh, the well-off farmers mostly developed Pangasius aquaculture using commercial feed regularly and farmers could have 5 farm components (fish, crop, vegetable, livestock and poultry), but the size of the components was small (Verdegem, 2005). The reuse of pond-mud and the polyculture was well appreciated by farmers and extension services. Applying a high level of both feed and fertilizer gave high positive nutrient balances for the pond. Farmer used 74.69 tonnes feed per hectare of pond (Ali et al., 2011) assuming that $30 \%$ of the nitrogen in the feed is converted into fish flesh and the reminder are deposited as bottom sediments in the pond (Rahman, 2004). The bottom sediment is enriched with organic matter, nitrogen, phosphorous, and macro and micronutrients (Rahman et al., 2004) and the value of these nutrients for crop production is potentially high (Voss et al., 1999). The bottom sediments are usually removed in 1 to 4 years intervals $(2.27 \pm 0.81)$ and placed on the dyke for repairing. Using pond sediments on the dikes resulted in higher plant yields and improved some of the soil fertility characteristics (Verdegem, 2005). Thus, the gross margins of the entire pond-dyke systems could be maximized to a greater extent through further research on the potential use of Pangasius pond sediments for diversified productive agricultural practices. Ideally, the Integrated Agriculture Aquaculture (IAA) approach results in increased income diversification and intensification, improved natural resource efficiency, increased productivity (Lightfoot et al., 1992) and the IAA approach, is considered a sustainable farming model for small-holder farming households (Prein, 2002).

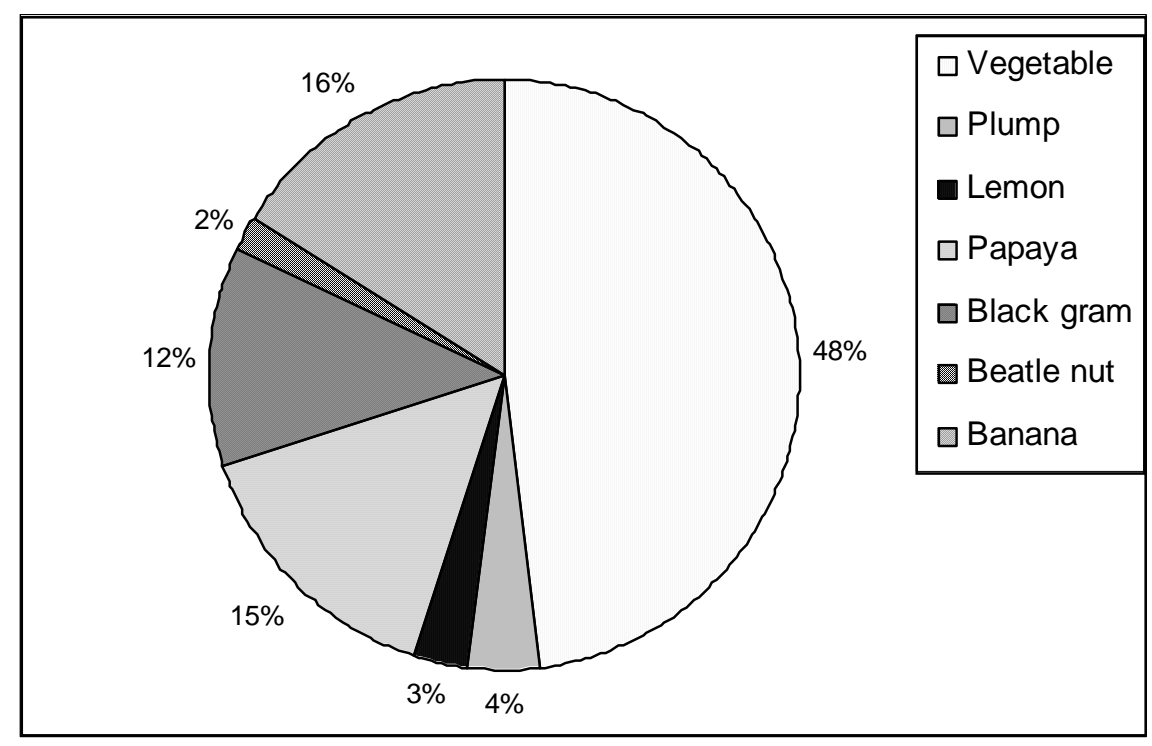

Fig. 5. Use of Pangasius pond dykes for producing different crops (source of data: farm survey)

Pangasius farms influenced positively the production of rice in the surrounding agricultural land other than dyke. Individually, a farm increased rice production of 93\% surrounding agriculture farms and decreased of $7 \%$ farms. The findings indicated that most of the farms developed in less productive upland rice field they enhanced crop production in its surrounding areas. However, Karim (2006) provided contradictory statement and he also found that the yields of most of the field crops had declined following the start of shrimp cultivation which might be due to the negative affects of saline water on the surrounding crop land. Production of wheat, jute and sugarcane has been affected seriously, and now it is not possible to grow these crops due to soil salinization. This clearly indicates that land based freshwater aquaculture has potential scope to increase agricultural production in a sustainable way. 
Inland aquaculture relies on the use of freshwater that mainly produces fish and crustaceans (Verdegem et al., 2006). Underground water mainly used in Pangasius aquaculture as well as a minimal level of surface water from river and beel (Fig. 6). The water exchange rate varied from $20 \%$ to $70 \%$ (mean: 47.23 \pm 5.34 ) of Pangasius pond water for 1-6 (mean: $2.17 \pm 0.45$ ) times during a production cycle of 6-8 months. Such level of water exchange is very minimal compared to daily water exchange in Pangasius farms in Vietnam (Phan et al., 2009) that might have several water quality implications demanding further research attention.

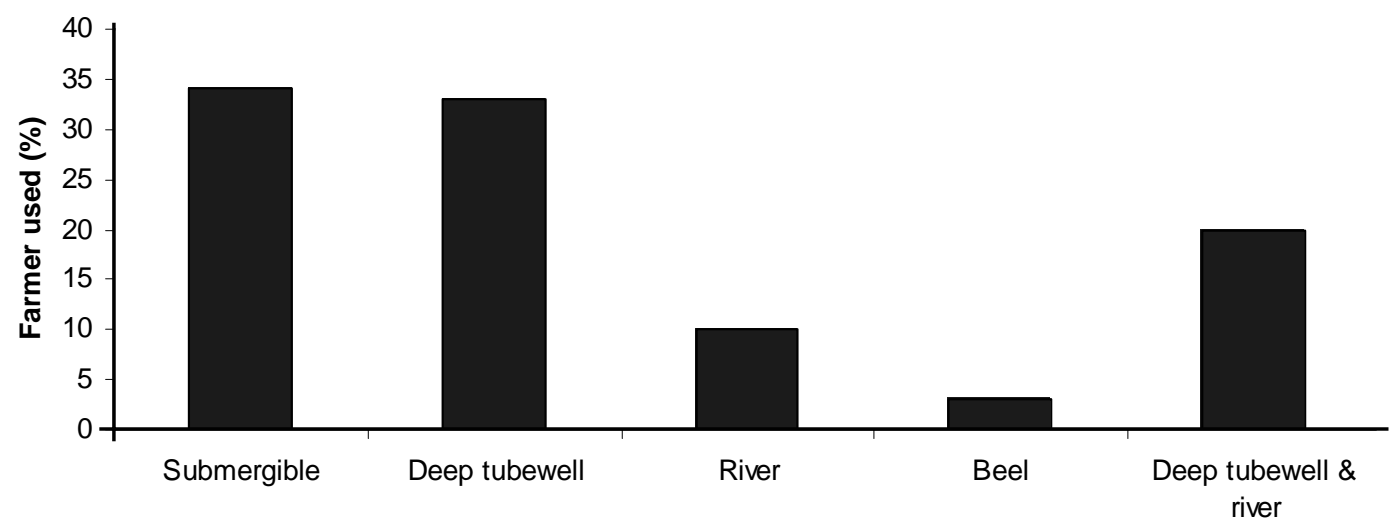

Source of water

Fig. 6. Sources of water for Pangasius farming in the study area area (source of data: farm survey)

Pangasius farms discharge pond water into rice fields without being treated, which led to negative impacts on the environment. Prein (2002) reported that the water and nutrients lost through drainage from aquaculture ponds can also be used to irrigate or to fertilize crops, either on the dyke or in adjacent ricefields. Nearby agriculture farmer can reduce 30\% fertilizer cost and $40 \%$ irrigation cost by using discharging wastewater of Pangasius farm. Thus, the use of discharge water enhanced productivity of rice fields in the adjacent farms by $10 \%$. A similar trend also reported for pangasius farming in Mymensingh area (Khan, 2009).

\section{Farming communities}

The farming communities are relatively young, with the age of farm owners ranging from 23-60 years old (mean: $38.4 \pm 9.90$ ). More than $20.0 \%$ farmers completed primary education, $30.0 \%$ Secondary School Certificate (SSC), 23.3\% Higher Secondary certificate (HSC) and 26.7\% Bachelor degree, which were higher than national literacy level of $65 \%$ (BBS, 2002). This suggested that mainly educated generations are engaged in Pangasius farming and showing behavioral characteristics of aquaculture entrepreneurship. The household size of the farmer family was usually consisted $5.17 \pm 1.42$ members (ranging from 3 to 10) while the national average family size of Bangladesh was 4.89 in 2004 [Bangladesh Bureau of Statistics (BBS), 2004]. In the present study, the primary occupation was considered the occupation from which most of the income was earned and it was found that $56.7 \%$ and 43.3\% of farmers took farming as their primary and secondary occupation, respectively. Table 1 suggests that $13.3 \%$ farmers have no secondary occupation and only Pangasius farming contributed to their household income. 
Table 1. Primary and secondary of Pangasius farmer in the study area (source of data: farm survey)

\begin{tabular}{|l|c|c|c|c|}
\hline \multirow{2}{*}{ Activities } & \multicolumn{2}{|c|}{ Primary occupation } & \multicolumn{2}{c|}{ Secondary occupation } \\
\cline { 2 - 5 } & No. of farmer (n) & \% of farmer & No. of farmer (n) & \% of farmer \\
\hline $\begin{array}{l}\text { Pangasius } \\
\text { farming }\end{array}$ & 34 & 56.7 & 26 & 43.3 \\
\hline $\begin{array}{l}\text { Aqua-feed } \\
\text { business }\end{array}$ & 4 & 6.7 & 6 & 10 \\
\hline Business & 10 & 16.7 & 6 & 10 \\
\hline Agriculture & 6 & 10 & 14 & 23.3 \\
\hline Service & 6 & 10 & 0 & 0 \\
\hline None & 0 & 0 & 8 & 13.3 \\
\hline
\end{tabular}

The average annual household income of the farmer indicated that a significant amount of income derived from the Pangasius farming (Fig. 7) followed by business which also related to Pangasius aquaculture support services (e.g. feed business). The annual income of the Pangasius pond varied from US\$ 1362.11 to 3952.56/ha (mean: $2451.19 \pm 978.38$ ) whereas agricultural lands varied from US\$285.71 to $428.57 / \mathrm{ha}$ (mean: $355.27 \pm 45.76$ ) that is about 7 times higher than agricultural land. As a result, people were engaged in Pangasius aquaculture for getting higher and quick economic return. A similar trend has also been reported for the shrimp farming system in Rampal upazila of Bagerhat district (Karim, 2006).

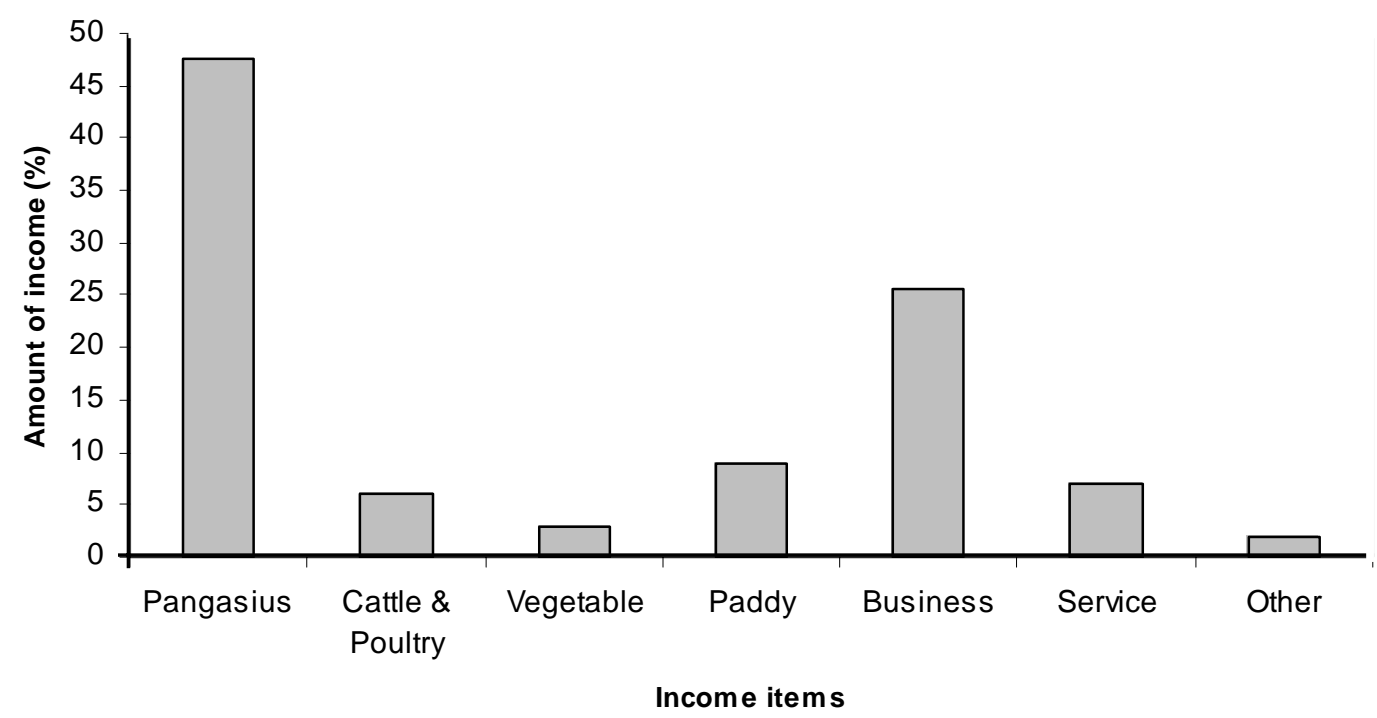

Fig. 7. Annual household income of Pangasius farmer (source of data: farm survey).

\section{Conclusion}

Mainly middle aged and educated people were involved in Pangasius aquaculture, predicting further entrepreneurial growth of Pangasius farming in Mymensingh region of Bangladesh. Pangasius farming added lease value to upland rice fields as well as increased rice productivity of the surrounding upland rice-field. The dyke of Pangasius farm was not efficiently used which predicts that there is a potential of integrated aquaculture farming in aquaculture dominating area. Thus, on-farm action research and development initiatives could be taken in this regard through the collaborative efforts of government and non-government organizations. 


\section{Acknowledgement}

This paper is an outcome of a research project funded by BAURES (Bangladesh Agricultural University Research System), Bangladesh Agricultural University, Mymensingh. The authors would like to thank pangasius farmer for their cordial help in this study.

\section{References}

Ahmed N., Alam, M.F. and Hasan, M.R. 2010. The economics of sutchi catfish (Pangasianodon hypophthalmus) aquaculture under three different farming systems in rural Bangladesh. Aquaculture Research, 41: 1668-1683.

Ali, H. 2009. Assessment of stakeholders' perceptions on Pangasius Aquaculture Dialogue (PAD) standards in two villages, Mymensingh, Bangladesh. MS Thesis. Department of Aquaculture, Bangladesh Agricultural University, Mymensingh, Bangladesh.

Ali, H. 2010. Cluster analysis of Pangasius aquaculture in Bangladesh based on geographical location and distribution. Unpublished field report. SEAT project, Bangladesh Agricultural University, Mymensingh and University of Stirling, UK.

Ali, H., Haque, M.M. and Belton, B. 2011. Pangasius aquaculture in Bangladesh: an overview. Aquaculture research (Submitted).

BBS, 2002. Statistical year book of Bangladesh. Bangladesh Bureau of Statistics, Statistical division, Government of the People's Republic of Bangladesh, Dhaka, 660 pp.

BBS, 2004. Bangladesh Bureau of Statistics. Statistics Division. Ministry of planning, Government of the People's Republic of Bangladesh, Dhaka, 673 pp.

DoF. 2009. Fishery Statistical Yearbook of Bangladesh. Fisheries Resources Survey System, Department of Fisheries, Ministry of Fisheries and Livestock, Dhaka, Bangladesh.

DoF. 2010. Fishery Statistical Yearbook of Bangladesh. Fisheries Resources Survey System, Department of Fisheries, Ministry of Fisheries and Livestock, Dhaka, Bangladesh.

Edwards, P. and Hossain, M.S. 2010. Bangladesh Seeks Export Markets for Striped Catfish. Global Aquaculture Advocate, May/June, 65-68 pp.

Food and Agriculture Organization (FAO). 2009. The State of World Fisheries and Aquaculture. Fisheries Department. FAO Fisheries Technical Paper No.500, pp 196. Food and Agriculture Organization (FAO) of the United Nations, Rome, Italy.

Griffin, K., Khan, A.R. and Ickowitz, A. 2002. Property and the Distribution of Land. Journal of Agrarian change. 2(3): 279-330.

Haque, M.M. 2009. Assessment of Stakeholders' Perceptions on Pangasius Aquaculture Dialogue (PAD) Standards in two Pangasius Farming Villages in Bangladesh. A working paper submitted to DelPHE Project, Faculty of Fisheries, Bangladesh Agricultural University, Mymensingh, Bangladesh.

Hossain, M.S. and Lin, C.K. 2001. Land Use Zoning for Integrated Coastal Zone Management: Remote Sensing, GIS and RRA Approach in Cox's Bazar Coast, Bangladesh. ITCZM Monograph No. 3, 25pp.

Karim, M.R. 2006. Brackish-water Shrimp CultivationThreatens Permanent Damage to Coastal Agriculture in Bangladesh. In: C.T. Hoanh, T.P. Tuong, J.W. Gowing and B. Hardy (eds.). Environment and Livelihoods in Tropical Coastal Zones. p-61.

Khan M. 2009. Water Use for Pangasius Aquaculture: Potential for Reuse of Discharged farm Water. MS thesis, Department of Aquaculture, Bangladesh Agricultural University, Mymensingh. Bangladesh.

Lightfoot, C., van Dam, A. and Costa-Pierce, B. 1992. What's happening to rice yields in rice-fish systems? In: C.R. dela Cruz, C. Lightfoot, B.A. Costa-Pierce, V.R. Carangal and M.P. Bimbao (eds.) Rice-fish research and development in Asia, pp. 77184. Proceedings of ICLARM Conference, Manila, Philippines.

Munir, S.A.M. 2009. Socio-economic impacts and sustainability of Pangasius (pangasianodon hypophthalmus) farming in Trishal Upazila under Mymensingh, Bangladesh. MS thesis, Institute of Aquaculture, University of Stirling, Stirling, Scotland, UK.

PDOICZMP (Program Development Office for Integrated Coastal Zone Management Plan) .2004. Proceedings of Technical Discussion on Coastal Land Zoning. PDO-ICZMP, Water Resources Planning Organization, Dhaka, Bangladesh, 80 pp.

Phan L.T., Bui, M.B., Nguyen, T.T.T., Gooley, G.J., Ingram, B.A., Nguyen, H.V., Nguyen P.T. and De Silva, S.S.. 2009. Current status of farming practices of striped catfish, Pangasianodon hypophthalmus in the Mekong Delta, Vietnam. Aquaculture, 296: 227-236.

Prein, M. 2002. Integration of aquaculture into crop-animal systems in Asia. Agriculture System 71: 127-146.

Primavera, J.H. 2006. Overcoming the impacts of aquaculture on the coastal zone. Ocean \& Coastal Management, 49: 531-545 
Rahman M.M. 2004. Evaluation of mixed feeding schedule with varying dietary protein content on the growth performance and reduction of cost of production for pangas with silver carp. MS thesis, Department of Aquaculture, Bangladesh Agricultural University, Mymensingh, Bangladesh.

Rahman M.M., Yakupitiyage A. and Ranamukhaarachchi, S.L. 2004. Agricultural use of fishpond sediment for environmental amelioration. Thammasat International Journal of Science and Technology, 9: 1-10.

Sarker M.T. 2000. Pangus Chash Babastapana (Management of Pangus culture). A Fisheries leafleat. Sheuli, Comilla Cantt., Comilla, Bangladesh (in Bengali).

Verdegem, M.C.J., Bosma, R.H. and Verreth, J.A.V. 2006. Reducing water use for animal production through aquaculture. Water Resources Development, 22 (1): 101-113.

Verdegem, M.C.J. 2005. Improved resource use efficiency in Asian integrated pond-dike systems - PONDLIVE. Final report of 5th Framework Programme.

Voss R.D., Sawyer, J.E., Mallarino, A.P. and Killorn, R. 1999. General guide for crop nutrient recommendations in lowa, Department of Agronomy. lowa State University. 